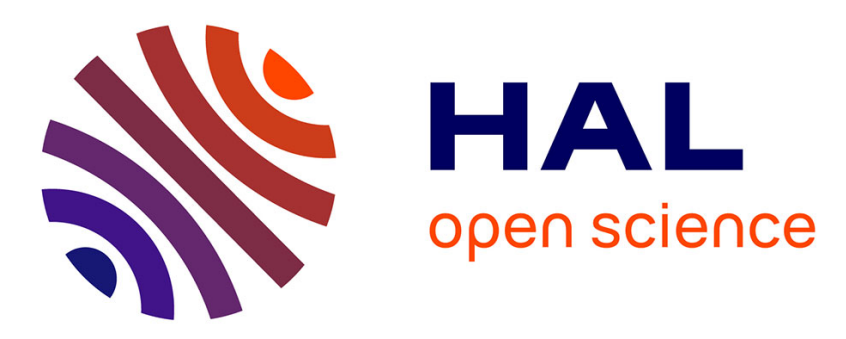

\title{
Theory of microbial coexistence in promoting soil-plant ecosystem health
}

Na Zhang, Naoise Nunan, Penny Hirsch, Bo Sun, Jizhong Zhou, Yuting Liang

\section{To cite this version:}

Na Zhang, Naoise Nunan, Penny Hirsch, Bo Sun, Jizhong Zhou, et al.. Theory of microbial coexistence in promoting soil-plant ecosystem health. Biology and Fertility of Soils, 2021, 57, pp.897-911. 10.1007/s00374-021-01586-w . hal-03336516

\section{HAL Id: hal-03336516 https://hal.science/hal-03336516}

Submitted on 5 Oct 2021

HAL is a multi-disciplinary open access archive for the deposit and dissemination of scientific research documents, whether they are published or not. The documents may come from teaching and research institutions in France or abroad, or from public or private research centers.
L'archive ouverte pluridisciplinaire $\mathbf{H A L}$, est destinée au dépôt et à la diffusion de documents scientifiques de niveau recherche, publiés ou non, émanant des établissements d'enseignement et de recherche français ou étrangers, des laboratoires publics ou privés. 
Niche difference (ND) and fitness difference (FD) (1) based on Lotka-Volterra competition model (Chesson, 2000, 2013)

$$
\begin{gathered}
\mathrm{ND}=1-\rho=1-\sqrt{\frac{\alpha_{i j} \times \alpha_{j i}}{\alpha_{j j} \times \alpha_{i j}}} \\
\mathrm{FD}=\frac{f_{j}}{f_{i}}=\sqrt{\frac{a_{i j} \times \alpha_{i j}}{a_{i j} \times a_{j i}}}
\end{gathered}
$$

where $\alpha_{i j}$ describes the per capita effect of species $j$ on species $i$.

(2) based on MacArthur's consumer-resource model (Carroll et al., 2011)

$$
\begin{gathered}
\mathrm{s}_{i}=\frac{\mu_{i, 0}-\mu_{i, j}}{\mu_{i, 0}} \\
\mathrm{ND}=1-\prod_{i=1}^{\mathrm{n}} \mathrm{s}_{i}^{1 / \mathrm{n}} \\
\mathrm{FD}=\exp \left[\left(\overline{(\ln S)^{2}}-\overline{(\ln \mathrm{S})^{2}}\right)^{1 / 2}\right]
\end{gathered}
$$

$S_{i}$ is the sensitivity to competition, where $\mu_{i, 0}$ and $\mu_{i j}$ is the per capita growth rate of invader $i$ in the absence and presence of the

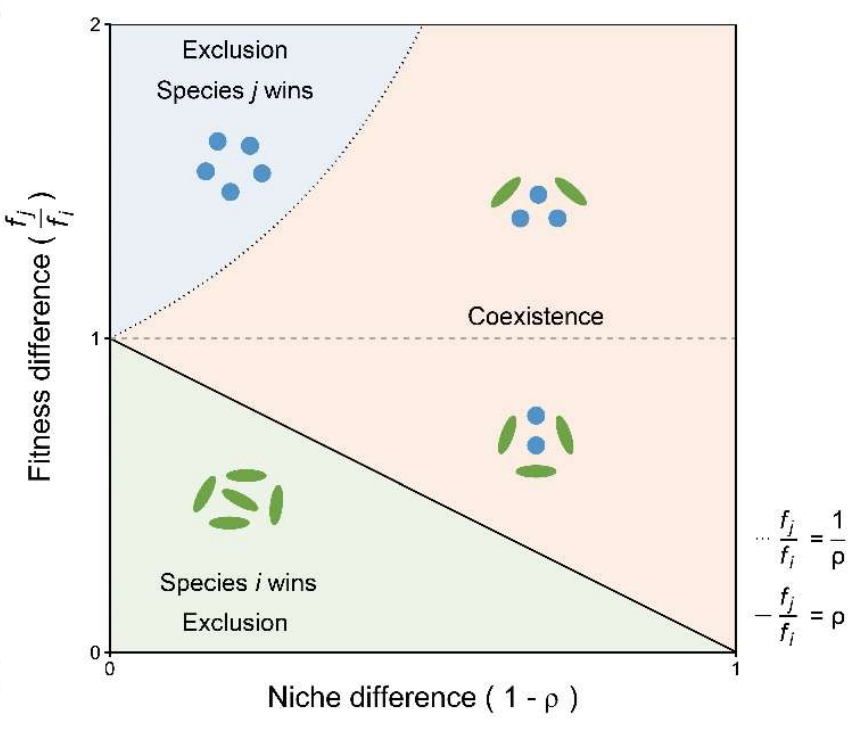

2 Figure 1 The conceptual diagram of modern coexistence theory. The competitive

3 outcome is determined by the balance between niche difference (ND) and fitness

4 difference (FD), which can be calculated based on the Lotka-Volterra competition

5 model (Chesson, 2000, 2013) or MacArthur's consumer-resource model (Carroll et

6 al., 2011). The dotted and solid lines represent the boundaries where $f_{j} / f_{i}$ equals $1 / \rho$

7 or $\rho$, respectively. The right area indicates the region where coexistence occurs; the

8 top and bottom areas indicate where species $j$ or $i$ is dominant, respectively. Figure

9 modified from Ke and Letten (Ke and Letten, 2018). 


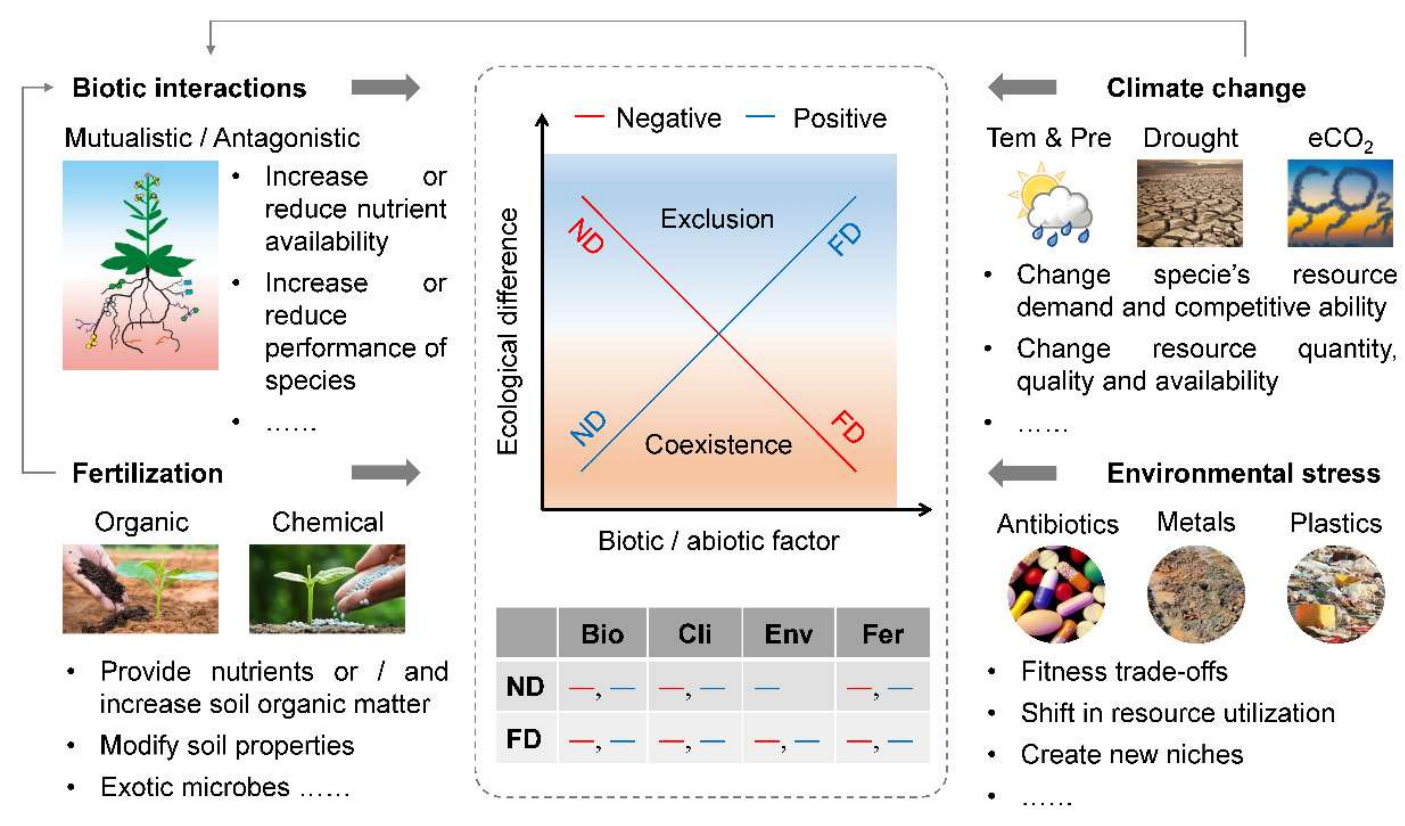

11 Figure 2 Graphical presentation of possible effects of biotic and abiotic factors on

12 niche and fitness differences. ND: niche difference; FD: fitness difference. Bio: biotic

13 interactions; Cli: climate change; Env: environmental stress; Fer: fertilization. Red

14 and blue lines indicate negative and positive relationships, respectively. Gray thin

15 arrows indicate indirect impact pathways. 


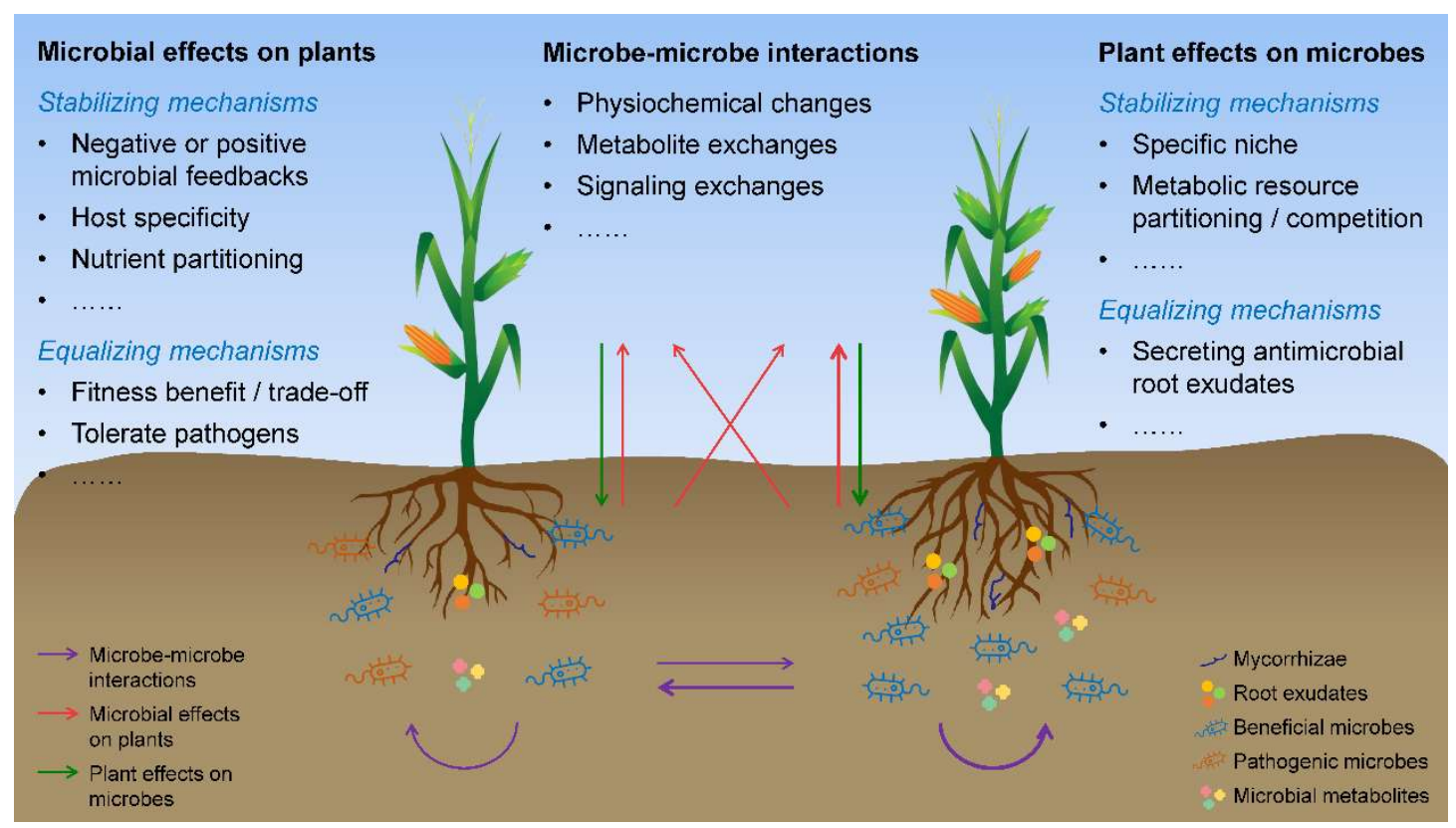

17 Figure 3 Schematic illustrating soil microbe-microbe interactions and plant-microbe

18 interactions through modern coexistence theory. The conceptual model of microbe-

19 microbe interactions and plant-microbe interactions is modified after Bever's model

20 of pairwise plant-soil feedback and its derived framework (Bever et al., 1997; Bever,

21 2003; Kandlikar et al., 2019; Ke and Wan, 2019). The interactions among microbes

22 can be mutualistic or antagonistic. Microbial effects on plants and plant effects on mi-

23 crobes can be positive or negative. 